\title{
Associations of sperm DNA fragmentation with lifestyle factors and semen parameters of Saudi men and its impact on ICSI outcome
}

Basmah Al Omrani ${ }^{1}$, Nadia Al Eisa ${ }^{1}$, Murid Javed ${ }^{2 *}$ (D, Maher Al Ghedan ${ }^{3}$, Hamoud Al Matrafi ${ }^{4}$ and Hamad Al Sufyan ${ }^{2}$

\begin{abstract}
Background: Male factor infertility is quite common as 30-50\% of infertility cases are due to sperm defects. The high sperm DNA fragmentation is one of the causes of male factor infertility. Many factors cause sperm DNA fragmentation and could be testicular or post-testicular. The purpose of this study was to assess relationships among sperm DNA fragmentation, lifestyle factors and semen values of Saudi men and to determine impact of sperm DNA fragmentation on ICSI cycle outcome.

Methods: The duration of this study was from January 2015 to June 2016. The cases with female factor infertility were excluded. In total 94 couples were selected for investigation. The study parameters were male age, body mass index, smoking, semen values, \% sperm DNA fragmentation, fertilization rate and pregnancy outcome. The ICSI procedure was performed in all patients per standard protocol. The semen samples were grouped based on \% sperm DNA fragmentation into < 15\%, 15-30 and $>30 \%$ which corresponded to low, moderate and high sperm DNA fragmentation, respectively.

Results: There was no difference in ICSI outcome in low and moderate sperm DNA fragmentation, however, in high sperm DNA fragmentation no patient achieved pregnancy. In this study, 53.19\% Saudi men had low, 32.98\% moderate and $13.83 \%$ high DFI. Semen volume, sperm morphology and fertilization rate did not show any correlation trend with DNA fragmentation, however, sperm concentration and motility were negatively correlated in all DFI categories. The BMI was positively correlated in moderate DFI category and smoking was positively correlated with low DFI category. The age was positively correlated in moderate and high DFI categories.

Conclusions: The results of this study indicated that 14\% Saudi men had high DNA fragmentation. The BMI was positively correlated in moderate DFI category and smoking was positively correlated with low DFI category. The age was positively correlated in moderate and high DFI categories.
\end{abstract}

Keywords: Sperm DNA fragmentation, Body mass index, ICSI, Infertility, Male factor, Smoking

\footnotetext{
* Correspondence: murid.javed@gmail.com

${ }^{2}$ Assisted Reproductive Technology Laboratories, Thuriah Medical Center,

Riyadh, Saudi Arabia

Full list of author information is available at the end of the article
}

(c) The Author(s). 2018 Open Access This article is distributed under the terms of the Creative Commons Attribution 4.0 International License (http://creativecommons.org/licenses/by/4.0/), which permits unrestricted use, distribution, and reproduction in any medium, provided you give appropriate credit to the original author(s) and the source, provide a link to the Creative Commons license, and indicate if changes were made. The Creative Commons Public Domain Dedication waiver (http://creativecommons.org/publicdomain/zero/1.0/) applies to the data made available in this article, unless otherwise stated. 


\section{Background}

Infertility is failure to achieve a clinical pregnancy after 12 months or more of regular unprotected sexual intercourse [1]. It is a common problem, with recent publications quoting a 9 to $18 \%$ prevalence in the general population [2]. It may be due to male or female factors or unexplained where after an elaborate workup no apparent reason for infertility is found [3]. About 30-50\% of infertility cases are attributed to sperm defects $[4,5]$. Defective sperm conditions include very low sperm concentration, inadequate sperm motility and morphological abnormalities. The percentage of cells exhibiting fragmented DNA is represented by the DNA fragmentation index (DFI) [6]. The infertile males are found to have a higher percentage of sperm with defective DNA than fertile controls [7-9]. Therefore, DFI is recommended as an appealing fertility predictive element [10-12].

The causes of sperm DNA damage are numerous, of complex nature and could be testicular or post-testicular [13]. These may include defects in spermatogenesis (e.g., genetic or developmental abnormalities) and testicular or post-testicular injury (e.g., gonadotoxins, hyperthermia, oxidants, and endocrine abnormalities). It has been suggested that protamine deficiency (with consequent aberrant chromatin remodeling), reactive oxygen species and abortive apoptosis may be responsible for sperm DNA damage [14].

Lifestyle factors like increased body mass index (BMI) [15], scrotal hyperthermia [16, 17] and smoking [18] increase DFI. An increased risk of cancer in offspring from fathers with increased level of DFI because of smoking has been reported [19].

Intracytoplasmic sperm injection (ICSI) made a paradigm shift of male infertility treatment. It is recommended even in couples with high level of DFI. The Sperm Chromatin Dispersion (SCD) assay is a validated procedure for assessment of DFI [20]. The DFI has been demonstrated to affect naturally induced pregnancy $[21,22]$ or pregnancy through ART. Furthermore, the high level of DFI $(\geq 27 \%)$ has been shown to reduce fertility after ART procedure [23]. The objectives of this study were to determine the level of DFI in Saudi men, to see its impact on ICSI outcome and to evaluate its correlations with lifestyle factors (age, body mass index and smoking) and semen parameters.

\section{Methods}

We retrospectively conducted a systematic review of data from 94 Saudi men tested for sperm DNA fragmentation by SCD assay before undergoing ICSI from Jan 2015 to June 2016 at an infertility clinic in Riyadh, Saudi Arabia. The cases with female factor infertility were excluded. In total 94 couples were selected for investigation. The study parameters were sperm DFI, semen values, male age, BMI, smoking, fertilization and pregnancy rate. The semen samples were divided into following categories based on DFI: $<15 \%, 15-30 \%$ and $>30$, which corresponded to low, moderate and high DFI. Thuriah institutional review board approved this study.

\section{Semen analysis}

The patients were instructed to abstain for 3-5 days before providing semen sample by masturbation. After complete liquefaction, semen volume $(\mathrm{mL})$, sperm concentration $\left(10^{6} / \mathrm{mL}\right)$, motility (\%) and presence of round sperm $\left(10^{6} / \mathrm{ml}\right)$ were determined. The percent morphology was assessed from a stained smear under $100 \times$ oil immersion objective by analysing 200 spermatozoa. The sample was considered normal if it had $1.5-6 \mathrm{ml}$ volume, $\geq 15$ million $/ \mathrm{mL}$ sperm concentration, $\geq 40 \%$ progressive motility and $\geq 4 \%$ normal morphology.

\section{Sperm chromatin dispersion assay}

The SCD assay was conducted using Halosperm G2 ${ }^{\circ}$ kit (Halotech $^{\circ}$, Spain). At least 300 spermatozoa were scored under an inverted bright-field microscope for each sample. The normal sperm without fragmented DNA showed big or medium size halo and the sperm with fragmented or degraded DNA showed no halo.

\section{Ovarian stimulation, ICSI and embryo culture}

Ovarian stimulation in female partner was achieved using agonist or antagonist protocol. Oocytes were collected $36 \mathrm{~h}$ post hCG injection. Oocyte denudation and ICSI were performed per standard procedure [24]. On the day of egg collection, the male partner was asked to produce semen sample which was processed for ICSI. The fertilization was checked $16-18 \mathrm{~h}$ post-ICSI. Presence of 2 pronuclei and two polar bodies were recognized as normal fertilization. Oocytes without obvious pronuclei were considered unfertilized. Oocytes with a single pronucleus or more than two pronuclei were considered abnormal fertilization and not included in the study. Embryos were cultured in an atmosphere of $6 \%$ $\mathrm{CO}_{2}$ in air. Morphological assessment of each embryo was performed daily based on \% cytoplasmic fragmentation. Embryos were graded on a scale of 1 to 5 where 1 was considered the best grade with $10 \%$ or less fragmentation. Embryo transfer was performed on day 3. Per our clinic policy; 2 embryos were transferred in patients less than 35 yrs., 3 embryos in patients from 36 to 39 yrs. and 4 embryos in patients 40 yrs. or more. The extra embryos were cryopreserved for subsequent embryo transfers. Biochemical pregnancy rate was calculated based on $\beta$ hCG test 14 days post oocyte retrieval. 


\section{Statistical analysis}

The data were analyzed by Statistical Package for Social Sciences (SPSS), Version 23. The main dependent variable in this study was ICSI cycle outcome (successful or unsuccessful). Descriptive statistics were used to calculate mean, medians, maximum and minimum for age, male BMI, semen volume, sperm concentration, sperm motility and morphology. The DFI was categorized into $<15 \%, 15-30 \%$ and $>30$, which corresponded to low, moderate and high DFI. The independent t-test was used to detect the difference between two independent groups of ICSI, while Mann-Whitney test was used to assess the significant differences of non-parametric continuous variables (such as semen parameters). Chisquare test was used to assess the significant difference between categorical variables. Pearson's correlation was used to assess the strength and significance of association between parametric variables, while Spearman's correlations were used in non-parametric variables. The degree of association was represented by the correlation coefficient and a statistically significant difference was detected when $P<0.05$.

\section{Results}

From 94 men, 53.19\% had low, 32.98\% moderate and 13. $83 \%$ high DFI. The Mean \pm SD values for low, moderate and high groups were; $10.46 \pm 3.31,20.80 \pm 4.68$ and 38 . $54 \pm 10.14 \%$, respectively (Table 1 ). The distribution of DFI in Saudi sub-fertile men undergoing successful and unsuccessful ICSI treatment is presented in Table 2. The patients in successful group were those who achieved pregnancy in ICSI cycle. The number of embryos transferred in each group were similar. The indication was male factor infertility. There was no significant difference in ICSI outcomes in low $(P=0.597)$ and moderate $(P=0.235)$ DFI categories. In the high DFI category, no patient achieved pregnancy. There were non significant differences between successful and non-successful ICSI groups in regards to the semen parameters. Similarly, there were non significant differences between these two ICSI groups in regards to the age, BMI, and smoking (Table 3).

Table 1 Sperm DNA fragmentation categories in Saudi subfertile men undergoing ICSI $(n=94)$

\begin{tabular}{lllll}
\hline Category & Number (\%) & Mean \pm SD & Median & Range \\
\hline $\begin{array}{l}\text { Low DFI } \\
(<15 \%)\end{array}$ & $50(53.19)$ & $10.46 \pm 3.31$ & 10.94 & $2.57-14.90$ \\
$\begin{array}{l}\text { Moderate DFI } \\
(15-30 \%)\end{array}$ & $31(32.98)$ & $20.80 \pm 4.68$ & 19.80 & $15.28-29.73$ \\
$\begin{array}{l}\text { High DFI } \\
(>30 \%)\end{array}$ & $13(13.83)$ & $38.54 \pm 10.14$ & 34.43 & $31.16-67.75$ \\
\hline
\end{tabular}

Values are given as number, Mean $\pm S D$, Median and Range
The correlations between DFI categories, semen parameters and lifestyle factors are given in Table 4. Semen volume, sperm morphology and fertilization rate did not show any correlation trend with DNA fragmentation; however, sperm concentration and motility were negatively correlated in all DFI categories. The BMI was positively correlated in moderate DFI category and smoking was positively correlated with low DFI category. The age was positively correlated in moderate and high DFI categories.

\section{Discussion}

In this study, the lowest DFI value was $2.57 \%$ and the highest $67.75 \%$ in 94 Saudi men tested. In $53 \%$ men, the DFI value was $10.46 \pm 3.31 \%$. In the moderate and high DFI groups, these values were $20.80 \pm 4.68 \%$ and $38.54 \pm$ $10.14 \%$, respectively. In the high DFI group no pregnancy was achieved. The DFI has been related to fertility potential [21]. The DFI values are significantly higher in infertile as compared to those in fertile group [25]. A significant inverse correlation was established between DNA fragmentation and sperm concentration, total count, progressive motility (rapid and total) and normal morphology in subfertile and infertile men $(p<0.05)$ as compared to in fertile group [26] Normozoospermic men exhibited lower levels of DNA fragmentation than non-normozoospermic men. Therefore, it was suggested that DNA fragmentation testing and traditional semen analysis should be considered as complementary diagnostic tools in a comprehensive evaluation of male infertility [27].

In our study, the mean DFI value for high DFI group was $38.54 \%$ using the SCD assay. The DFI of $\geq 30 \%$ by SCD is considered of poor fertility potential. The other most commonly used techniques to assess sperm DNA integrity are the TUNEL, Comet and Sperm Chromatin Structural Assay (SCSA). A threshold value of 30\% DFI was reported for SCSA for IVF/ICSI cases and $20 \%$ for the TUNEL assay, although IVF and ICSI term pregnancies have been reported even with semen samples with much higher DFI values [28]. The oocytes and early embryos have the ability to repair sperm DNA damage, with the effect of such damage being dependent on the extent of chromatin damage and the capacity of oocytes to make repairs. This suggests that when sperm has extensively damaged DNA, the capacity of the oocyte to repair damaged DNA might be exceeded and high DFI $>30 \%$ may be incompatible with pregnancy [29] in couples with poor oocyte quality.

In the present study, fertilization rate was not different in DFI categories of Saudi men. This finding is in agreement with other studies [30-32]. However, one study found significant association between DFI and fertilization rate [10] which could most likely be due to 
Table 2 The distribution of DFI in Saudi sub-fertile men undergoing successful and unsuccessful ICSI treatment $(n=94)$

\begin{tabular}{|c|c|c|c|c|c|c|c|}
\hline \multirow[t]{2}{*}{ Category } & \multicolumn{3}{|c|}{ Values in Successful ICSI } & \multicolumn{3}{|c|}{ Values in Unsuccessful ICSI } & \multirow[t]{2}{*}{$P$ Value } \\
\hline & No. & Mean \pm SD & $\overline{\text { Median }}$ & No. & Mean \pm SD & $\overline{\text { Median }}$ & \\
\hline$\overline{\mathrm{DFI}}<15 \%$ & 7 & $9.83 \pm 3.58$ & 10.67 & 43 & $10.55 \pm 3.29$ & 11.21 & 0.597 \\
\hline DFI 15-30\% & 11 & $19.09 \pm 3.78$ & 17.47 & 20 & $21.73 \pm 4.93$ & 21.75 & 0.135 \\
\hline $\mathrm{DFI}>30 \%$ & 0 & 0 & 0 & 13 & $38.54 \pm 10.14$ & 34.43 & - \\
\hline
\end{tabular}

Values are given as Mean \pm SD and Median. The independent t-test and Chi square were used to compare groups

differences in the oocyte quality because the number of metaphase II oocytes and embryo quality are important factors affecting ICSI outcome. In this study, female age was $33 \pm 5.7$ yrs. The number of mature oocytes was $10.6 \pm 7.5$ and oocyte quality was similar in all groups as cases with female factor infertility were excluded.

The sperm DNA fragmentation has been attributed to a variety of intrinsic and extrinsic factors which could be of genetic or environmental origin. Majority of marriages in Saudi population happen in closely related individuals thereby causing some genetic concerns. Among the genetic factors, variations and polymorphisms in genes playing roles in genome integrity have been implicated in an increased risk of sperm DNA fragmentation. The chromosomal structural rearrangements, such as reciprocal translocations are associated with increased DNA damage in infertile men [33]. Analysis of genetic reasons of DNA fragmentation is beyond the scope of this study. A future study addressing this concern is direly needed.

Human sperm DNA is tightly packed. The condensation of nuclear chromatin takes place during the last stages of spermiogenesis and epididymal transport. A few important biochemical changes take place such as the replacement of lysine-rich histones with argininerich protamines. At the same time, bisulfidic bonds are formed between cysteine residues. In these ways, the nuclear chromatin is tightly packed to protect it from natural and chemical damaging factors. Abnormalities in sperm chromatin condensation may results in increased sperm DNA fragmentation [34].

This study found that age was significantly positively correlated with moderate and high DFI. This is consistent with an earlier study [35], which aimed to assess the outcomes of ICSI in patients with high DNA fragmentation. It found that male with high and moderate DFI were significantly older than those with the low DFI. This is in disagreement with another study [29] in which there was no significant difference when DFI in males above and below the median age was compared. This non-significant result could be attributed to the life style and young age of included males where maximum age was 48 years, while in the current study the male age reached 55 years.

Among the environmental factors, BMI, smoking and heat to the scrotum are major factors causing DNA fragmentation. In the present study, BMI was significantly correlated with the moderate and total DFI categories. This is in agreement with a study conducted in USA [36], where multiple linear regression detected a significant association between obesity and sperm DNA fragmentation. It found men with BMI higher than 25 to have less DNA integrity, thus, patients should be advised to reduce their body weight in order to achieve maximum possible fertility. This is inconsistent with the

Table 3 The distribution of social and semen characteristics of Saudi sub-fertile men undergoing successful or unsuccessful ICSI treatment

\begin{tabular}{|c|c|c|c|c|c|c|c|}
\hline \multirow[t]{2}{*}{ Parameter } & \multicolumn{3}{|c|}{ Values in Successful ICSI } & \multicolumn{3}{|c|}{ Values in Unsuccessful ICSI } & \multirow[t]{2}{*}{$P$ Value } \\
\hline & No. & Mean \pm SD & Range & No. & Mean \pm SD & Range & \\
\hline Male age $23-36$ yrs & 12 & $32.75 \pm 2.80$ & $28-36$ & 41 & $32.56 \pm 2.67$ & $25-36$ & 0.83 \\
\hline Male age $37-57$ yrs & 6 & $42.17 \pm 3.19$ & $37-45$ & 35 & $44.43 \pm 5.39$ & $37-55$ & 0.32 \\
\hline $\mathrm{BMI}=<30 \mathrm{Kg} / \mathrm{m}^{2}$ & 17 & $22.65 \pm 1.93$ & $19.4-26.7$ & 64 & $23.89 \pm 2.61$ & $19-30$ & 0.48 \\
\hline $\mathrm{BMI}=>30 \mathrm{Kg} / \mathrm{m}^{2}$ & 1 & 32.0 & & 12 & $32.44 \pm 2.35$ & $30-36$ & - \\
\hline Smoker & 8 & & & 34 & & & 0.078 \\
\hline Non-smoker & 10 & & & 42 & & & \\
\hline \multicolumn{8}{|l|}{ Semen Variables } \\
\hline Volume (mL) & 18 & $2.72 \pm 1.15$ & $0.5-5$ & 79 & $2.86 \pm 1.13$ & $0.2-6$ & 0.154 \\
\hline Conc. $\left(10^{6} / \mathrm{mL}\right)$ & 18 & $67.94 \pm 74.64$ & $18-350$ & 79 & $64.13 \pm 43.61$ & $15-200$ & 0.628 \\
\hline Prog motility (\%) & 18 & $50.16 \pm 10.55$ & $40-80$ & 79 & $49.32 \pm 9.19$ & $38-76$ & 0.776 \\
\hline Abn. Morphology (\%) & 18 & $94.11 \pm 3.32$ & $88-98$ & 79 & $89.63 \pm 11.09$ & $15-98$ & 0.095 \\
\hline
\end{tabular}


Table 4 The correlations between sperm DFl, semen parameters, fertilization rate and lifestyle factors of the sub fertile men

\begin{tabular}{|c|c|c|c|}
\hline \multirow[b]{2}{*}{ Characteristics } & \multicolumn{3}{|l|}{ DFI\% ( $P$ value) } \\
\hline & $<15$ & $15-30$ & $>30$ \\
\hline Semen Volume $(\mathrm{mL})$ & $-0.06(0.68)$ & $0.209(0.258)$ & $0.18(0.556)$ \\
\hline Sperm Con. $\left(10^{6} / \mathrm{mL}\right)$ & $-0.02(0.88)$ & $-0.133(0.475)$ & $-0.009(0.976)$ \\
\hline Progressive Motility (\%) & $-0.36(0.008)^{* *}$ & $-0.334(0.06)$ & $-0.334(0.264)$ \\
\hline Sperm Morphology (\%) & $-0.096(0.509)$ & $-0.018(0.925)$ & $0.198(0.517)$ \\
\hline Fertilization Rate (\%) & $-0.022(0.878)$ & $0.05(0.790)$ & $0.497(0.084)$ \\
\hline Age (Yrs.) & $-0.273(0.366)$ & $0.603(0.001)^{* *}$ & $0.548(0.00)^{* *}$ \\
\hline BMI & $0.21(0.167)$ & $0.42(0.041)^{*}$ & $0.561(0.073)$ \\
\hline Smoking & $0.292(0.040)^{*}$ & $0.035(0.851)$ & $0.340(0.256)$ \\
\hline
\end{tabular}

${ }^{*} P<0.05$

${ }^{*} P<0.01$

findings of a study conducted in Czech [37], where no significant association between BMI and DFI was reported.

The smoking was significantly correlated with each of the high and total DFI categories. Smoking can affect the sperm by losing their ability to fight off free oxygen radicals in the seminal fluid which make the sperm more sensitive to oxidative stress. Therefore, the increases in the free radicals in the seminal fluid affect DFI, motility and fertilization. [29].

About 15\% of infertile Saudi men had normal semen parameters despite high DFI; therefore, testing DFI in addition to other semen parameters is beneficial [38] as the DFI evaluation may reveal a hidden abnormality in apparently normal sperm parameters [39].

\section{Conclusions}

In summary, results of this study indicated that $14 \%$ Saudi men had high DNA fragmentation. The BMI was positively correlated in moderate DFI category and smoking was positively correlated with low DFI category. The age was positively correlated in moderate and high DFI categories.

\section{Abbreviations}

ART: Assisted reproductive technology; BMI: Body mass index; DFI: DNA fragmentation index; DNA: Deoxyribonucleic acid; hCG: Human chorionic gonadotropin; ICSI: Intracytoplasmic sperm injection; SCD: Sperm chromatin dispersion; SPSS: Statistical package for social sciences

\section{Acknowledgements}

The authors thank King Saud University and Thuriah Medical Center for assistance in carrying out this study.

\section{Availability of data and materials}

Data were obtained from files of patients treated at Thuriah Medical Center. Literature search was conducted from PubMed, electronic journals, other internet sources and King Saud University Library. Further information is available by contacting Murid Javed at murid.javed@gmail.com.

\section{Authors' contributions}

$\mathrm{BO}$ and $\mathrm{MJ}$ conceived the idea, analyzed data and drafted the manuscript. NA supervised the study and critically reviewed the manuscript. HM and HS provided data and critically reviewed manuscript. All authors read and approved the final manuscript.

Ethics approval and consent to participate

Thuriah Institutional Review Board approval was obtained before accessing patient's files and conducting the study.

\section{Competing interests}

The authors declare that they have no competing interests.

\section{Publisher's Note}

Springer Nature remains neutral with regard to jurisdictional claims in published maps and institutional affiliations.

\section{Author details}

${ }^{1}$ Zoology Department, King Saud University, Riyadh, Saudi Arabia. ${ }^{2}$ Assisted Reproductive Technology Laboratories, Thuriah Medical Center, Riyadh, Saudi Arabia. ${ }^{3}$ Genetics Laboratory, Thuriah Medical Center, Riyadh, Saudi Arabia.

${ }^{4}$ Urology and Andrology Unit, Thuriah Medical Center, Riyadh, Saudi Arabia.

Received: 13 March 2018 Accepted: 11 May 2018

Published online: 19 May 2018

References

1. Zegers-Hochschild F, Adamson GD, de Mouzon J, Ishihara O, Mansour R, Nygren K, Sullivan E, Vanderpoel S. International Committee for Monitoring Assisted Reproductive Technology (ICMART) and the World Health Organization (WHO) revised glossary of ART terminology. Fertil Steril. 2009:92:1520-4

2. Hanson B, Johnstone E, Dorais J, Silver B, Peterson CM, Hotaling J. Female infertility, infertility-associated diagnoses, and comorbidities: a review. J Assist Reprod Genet. 2017;34(2):167-77. Published online 2016 Nov 5. https://doi.org/10.1007/s10815-016-0836-8.

3. Lessing JB, Amit A, Barak Y, Kogosowski A, Gruber A, Yovel I, David MP, Peyser MR. The performance of primary and secondary unexplained infertility in an in vitro fertilization-embryo transfer program. Fertil Steril. 1988;50(6):903-5.

4. Oehninger S. Clinical and laboratory management of male infertility: an opinion on its current status. J Androl. 2000;21:814-21.

5. Lamb DJ, Lipshultz LI. Male infertility: recent advances and a look towards the future. Curr Opin Urol. 2000;10:359-62.

6. Speyer BE, Pizzey AR, Abramov B, Saab W, Doshi A, Sarna U, Harper JC, Serhal P. Successful outcomes achieved in assisted reproduction cycles using sperm with high levels of high DNA stainability. Sys biol Reprod Med. 2015;61:293-9.

7. Hammoud AO, Gibson M, Peterson CM, Meikle AW, Carrell DT. Impact of male obesity on infertility: a critical review of the current literature. Fertil Steril. 2008;90:897-904.

8. Saleh RA, Agarwal A, Nada EA, El-tonsy MH, Sharma RK, Meyer A, Nelson DR, Thomas AJ. Negative effects of increased sperm DNA damage in relation to seminal oxidative stress in men with idiopathic and male factor infertility. Fertil Steril. 2003;79:1597-605.

9. Evenson DP, Larson KL, Jost LK. Sperm chromatin structure assay: its clinical use for detecting sperm DNA fragmentation in male infertility and comparisons with other techniques. J Androl. 2002;23:25-43.

10. Benchaib M, Braun V, Lornage J, Hadj S, Salle B, Lejeune H, Guerin JF. Sperm DNA fragmentation decreases the pregnancy rate in an assisted reproductive technique. Hum Reprod. 2003;18:1023-8.

11. Collins JA, Barnhart KT, Schlegel PN. Do sperm DNA integrity tests predict pregnancy with in vitro fertilization? Fertil Steril. 2008;89:823-31.

12. De La Calle JFV, Muller A, Walschaerts M, Clavere JL, Jimenez C, Wittemer C, Thonneau P. Sperm deoxyribonucleic acid fragmentation as assessed by the sperm chromatin dispersion test in assisted reproductive technology programs: results of a large prospective multicenter study. Fertil Steril. 2008;90:1792-9.

13. Henkel RR, Franken DR. Sperm DNA fragmentation: origin and impact on human reproduction. J Reprod Biotech Fertil. 2011;2:88-108.

14. Zini A, Albert O, Robaire B. Assessing sperm chromatin and DNA damage: clinical importance and development of standards. Andrology. 2014;2:322-5.

15. Oliveira JBA, Petersen CG, Mauri AL, Vagnini LD, Renzi A, Petersen B, Franco $J G$. Association between body mass index and sperm quality and sperm 
DNA integrity. A large population study. Andrologia. 2017; https:/doi.org/ 10.1111/and.12889.

16. Paul C, Teng S, Saunders PT. A single, mild, transient scrotal heat stress causes hypoxia and oxidative stress in mouse testes, which induces germ cell death. Biol Reprod. 2009;80:913-9.

17. Kanter M, Aktas C, Erboga M. Heat stress decreases testicular germ cell proliferation and increases apoptosis in short term: an immunohistochemical and ultrastructural study. Toxicol Ind Health. 2013;29:99-113.

18. Cui $X$, Jing $X$, Wu $X$, Wang $Z$, Li Q. Potential effect of smoking on semen quality through DNA damage and the downregulation of Chk1 in sperm. Mol Med Rep. 2016;14:753-6.

19. Rex AS, Aagaard J, Fedder J. DNA fragmentation in spermatozoa: a historical review. Andrology. 2017;5:622-30.

20. Perreault SD, Aitken RJ, Baker HW, Evenson DP, Huszar G, Irvine DS, Morris ID, Morris RA, Robbins WA, Sakkas D, Spano M, Wyrobek AJ. Integrating new tests of sperm genetic integrity into semen analysis: breakout group discussion. Adv Exp Med Biol. 2003;518:253-68.

21. Evenson D, Jost L, Marshall D, Zinaman M, Clegg E, Purvis K, De Angelis $P$, Claussen $\mathrm{O}$. Utility of the sperm chromatin structure assay as a diagnostic and prognostic tool in the human fertility clinic. Hum Reprod. 1999;14:1039-49.

22. Spano M, Bonde JP, Hjollund HI, Kolstad HA, Cordelli E, Leter G. Sperm chromatin damage impairs human fertility. The Danish first pregnancy planner study team. Fertil Steril. 2000;73:43-50.

23. Larson-Cook KL, Brannian JD, Hansen KA, Kasperson KM, Aamold ET, Evenson DP. Relationship between the outcomes of assisted reproductive techniques and sperm DNA fragmentation as measured by the sperm chromatin structure assay. Fertil Steril. 2003:80:895-902.

24. Larson K, Dejonge C, Barnes A, Jost L, Evenson D. Sperm chromatin structure assay parameters as predictors of failed pregnancy following assisted reproductive techniques. Hum Reprod. 2000;15:1717-22.

25. Wiweko B, Utami P. Predictive value of sperm deoxyribonucleic acid (DNA) fragmentation index in male infertility. Basic Clin Androl. 2017; https://doi. org/10.1186/s12610-016-0046-3.

26. Evgeni E, Lymberopoulos G, Gazouli M, Asimakopoulos B. Conventional semen parameters and DNA fragmentation in relation to fertility status in a Greek population. Eur J Obstet Gynecol Reprod Biol. 2015;188:17-23. https:// doi.org/10.1016/j.jogrb.2015.02.026. Epub 2015 Feb 26

27. Evgeni E, Lymberopoulos G, Touloupidis S, Asimakopoulos B. Sperm nuclear DNA fragmentation and its association with semen quality in Greek men. Andrologia. 2015;47(10):1166-74. https://doi.org/10.1111/and.12398. Epub 2015 Jan 14

28. Sergerie M, Laforest $G$, Bujan L, Bissonnette F, Bleau G. Sperm DNA fragmentation: threshold value in male fertility. Hum Reprod. 2005;20:3446-51.

29. Nicopoullos JD, Gilling-Smith C, Almeida PA, Homa S, Norman-Taylor JQ, Ramsay JW. Sperm DNA fragmentation in subfertile men: the effect on the outcome of intracytoplasmic sperm injection and correlation with sperm variables. BJU Inter. 2008;101:1553-60

30. Esbert M, Pacheco A, Vidal F, Florensa M, Riqueros M, Ballesteros A, Garrid N, Calderón G. Impact of sperm DNA fragmentation on the outcome of IVF with own or donated oocytes. RBM Online. 2011;23:704-10.

31. Virro MR, Larson-Cook KL, Evenson DP. Sperm chromatin structure assay $\left(\mathrm{SCSA}^{\circ}\right)$ parameters are related to fertilization, blastocyst development, and ongoing pregnancy in in vitro fertilization and intracytoplasmic sperm injection cycles. Fertil Steril. 2004;81:1289-95.

32. Speyer BE, Pizzey AR, Ranieri M, Joshi R, Delhanty JD, Serhal P. Fall in implantation rates following ICSI with sperm with high DNA fragmentation. Hum Reprod. 2010;25:1609-18.

33. Evgeni E, Charalabopoulos K, Asimakopoulos B. Human sperm DNA fragmentation and its correlation with conventional semen parameters. J Reprod Infertil. 2014;15:2-14.

34. Karydis S, Asimakopoulos B, Papadopoulos N, Vakalopoulos I, Al-Hasani S, Nikolettos N. ICSI Outcome is not associated with the incidence of spermatozoa with abnormal chromatin condensation. In Vivo. 2005;19(5):921-5.

35. Dar S, Grover SA, Moskovtsev SI, Swanson S, Baratz A, Librach CL. In vitro fertilization-intracytoplasmic sperm injection outcome in patients with a markedly high DNA fragmentation index (> 50\%). Fertil Steril. 2013;100:75-80.

36. Kort HI, Massey JB, Elsner CW, Mitchell-Leef D, Shapiro DB, Witt MA, Roudebush WE. Impact of body mass index values on sperm quantity and quality. J Androl. 2006;27:450-2.
37. Rybar R, Kopecka V, Prinosilova P, Markova P, Rubes J. Male obesity and age in relationship to semen parameters and sperm chromatin integrity. Andrologia. 2011;43:286-91.

38. Al Ghedan MH, Al Matrafi $H$, Al Sufyan $H, A$ Al Tannir M. Sperm DNA fragmentation in Saudi infertile men with normal standard semen parameters. Andrology. 2015;4:126-9.

39. Saleh RA, Agarwal A, Nelson DR, Nada EA, El-Tonsy MH, Alvarez JG, Thomas AJ Jr, Sharma RK. Increased sperm nuclear DNA damage in normozoospermic infertile men: a prospective study. Fertil Steril. 2002; 78:313-8.

\section{Ready to submit your research? Choose BMC and benefit from:}

- fast, convenient online submission

- thorough peer review by experienced researchers in your field

- rapid publication on acceptance

- support for research data, including large and complex data types

- gold Open Access which fosters wider collaboration and increased citations

- maximum visibility for your research: over $100 \mathrm{M}$ website views per year

At BMC, research is always in progress.

Learn more biomedcentral.com/submissions 